\title{
Metode Contrast Stretching untuk Perbaikan Kualitas Citra pada Proses Segmentasi Video
}

\author{
I Made Dwi Putra Asana ${ }^{1}$, I Made Oka Widyantara ${ }^{2}$, NMAED Wirastuti ${ }^{3}$, Ida Bagus Putu Adnyana ${ }^{4}$
}

\begin{abstract}
This paper proposed contrast stretching as image enhancement to improve the segmentation result on video segmentation process. The Video dataset used in this paper is a video monitoring of the coastline movement activity. The frame of the used video has composition of sunlight that varies according to the data acquisition time. A Technique is required to overcome the effects of sunlight on the video frame. Contrast stretching is implemented to improve the contrast of the frame so that the value of the object in the frame is clearly visible. Objects that are clearly visible on the frame can improve the results of the segmentation process. Evaluation of contrast stretching as preprocessing on the segmentation process is done with silhouette coefficient method. Silhouette coefficient is used to measure the validity of cluster generated in the segmentation process. Implementation of contrast stretching as preprocessing in image segmentation can produce better segmentation than without preprocessing. It was stated at the silhouette width of each image segmentation results. Silhouette width value of each testing is contrast stretching obtain $\mathbf{0 . 7 5 8 2}$ and without preprocessing is 0.7553 .
\end{abstract}

Intisari- Paper ini mengusulkan contrast stretching sebagai perbaikan kualitas citra untuk meningkatkan hasil segmentasi pada proses segmentasi video. Data video yang digunakan merupakan video pemantauan aktifitas pergerakan garis pantai. Frame dari video yang digunakan memiliki komposisi cahaya matahari berbeda-beda sesuai dengan waktu akuisisi data. Dibutuhkan suatu teknik untuk mengatasi pengaruh cahaya matahari pada frame video. Contrast stretching diimplementasikan untuk memperbaiki nilai kontras pada frame sehingga obyek pada frame terlihat jelas. Dengan obyek yang terlihat jelas pada frame dapat meningkatkan hasil dari proses segmentasi. Pengujian implementasi contrast stretching sebagai preprocessing pada proses segmentasi dilakukan dengan metode silhouette coefficient. Silhouette coefficient digunakan untuk mengukur validitas cluster yang dihasilkan dalam proses segmentasi. Implementasi contrast stretching sebagai preprocessing dalam segmentasi citra dapat menghasilkan segmentasi lebih baik dibandingkan tanpa preprocessing. Hal tersebut dinyatakan berdasarkan nilai silhouette width dari masing-masing hasil segmentasi citra. Nilai silhouette width dari pengujian preprocessing contrast stretching adalah 0,7582 dan tanpa preprocessing dengan nilai 0,7553 .

\footnotetext{
1,2,3 Magister Bisnis Telekomunikasi, Program Pascasarjana Teknik Elektro, Universitas Udayana, Kampus Sudirman, Denpasar, Bali, INDONESIA;

${ }^{4}$ Teknik Sipil, Universitas Udayana, Kampus Sudirman, Denpasar, Bali, INDONESIA

e-mail: ${ }^{1}$ putraasana.09@gmail.com, ${ }^{2}$ oka.widyantara@unud.ac.id,

${ }^{3}$ dewi.wirastuti@unud.ac.id ${ }^{4}$ bagusadnyana32@gmail.com
}

Kata Kunci- Segmentasi Video, Perbaikan Kontras,

I Made Dwi Putra Asana: Metode Contrast Stretching untuk ...

\section{Preprocessing, Contrast Stretching.}

\section{PENDAHULUAN}

Segmentasi video merupakan proses identifikasi region pada frame video yang mengacu pada homogenitas objek pada frame [1]. Video merupakan gabungan gambar yang dibaca secara berurutan dalam suatu waktu dengan kecepatan tertentu. Gambar yang membentuk video disebut sebagai frame dan kecepatan pembacaan gambar disebut dengan frame rate dengan satuan fps (frame per second) [2][3][4]. Pengolahan video dengan melakukan segmentasi pada frame merupakan pendekatan dasar dalam pengenalan pola pada sebuah frame. Dengan melakukan segmentasi dalam suatu frame, obyek dapat diambil secara terpisah sehingga dapat dijadikan masukan pada proses analisis gambar selanjutnya [5]. Segmentasi dapat berupa kumpulan piksel yang memiliki kemiripan ciri seperti warna, intensitas, tekstur, tingkat keabuan, dsb.[6][7]. Beberapa algoritma segmentasi telah diusulkan dengan hasil segmentasi yang baik untuk kondisi sederhana pada gambar. Permasalahan muncul ketika frame dengan kondisi yang kompleks seperti pencahyaan yang bervariasi, situasi iluminasi yang buruk, dan pengaruh lain diruang terbuka [8]. Sehingga dibutuhkan sebuah proses segmentasi yang baik untuk mengatasi permasalahan yang kompleks pada frame. Pada paper ini membahas segmentasi pada video pemantauan aktifitas garis pantai. Frame pada video pemantauan aktifitas garis pantai merupakan gambar berwarna dengan komposisi efek cahaya matahari yang berbeda sesuai dengan waktu akuisisi. Pengaruh cahaya matahari yang bervariasi pada daerah pantai menjadi masalah ketika melakukan pemisahan objek pada proses segmentasi [9]. Paper ini mengusulkan teknik perbaikan kontras untuk mengatasi permasalahan iluminasi pada frame video pemantauan aktifitas garis pantai, sehingga dapat meningkatkan kualitas hasil segmentasi.

Image Enhancement atau perbaikan kualitas citra adalah aksentuasi atau penajaman elemen-elemen dari sebuah gambar seperti garis pemisah atau pembatas (edge and boundaries) atau tingkat kontras yang dapat membuat tampilan grafik dari gambar tersebut lebih berguna untuk dianalisis dan ditampilkan. Proses image enhancement tidak memperbaiki atau meningkatkan kualitas dari informasi dan data yang sudah ada pada gambar. Proses tersebut meningkatkan rentang dinamis (dynamic range) dari elemen yang dikehendaki pada gambar sehingga elemen tersebut dapat diperhatikan atau dilihat lebih jelas. Image enhancement mencakup berbagai hal seperti: manipulasi kontras, pengurangan noise, penajaman garis batas (edge crispening and sharpening), interpolasi dan pembesaran gambar. Contrast stretching merupakan salah 
satu teknik perbaikan kualitas citra yang berdasarkan pada operasi titik. Contrast stretching berguna untuk meningkatkan kekontrasan gambar yang kurang baik diakibatkan oleh pencahayaan yang buruk atau sensor kamera yang kurang luas daya tangkapnya [10].

Contrast stretching diusulkan pada paper ini untuk mengatasi permasalahan komposisi cahaya pada frame sehingga dapat meningkatkan kualitas segmentasi. Implementasi contrast stretching dilakukan pada tahap preprocessing pada proses segmentasi. Preprocessing pada segmentasi citra merupakan pengolahan data asli sebelum dilakukan pemrosesan segmentasi dengan tujuan menghilangkan noise, memperjelas ciri data, atau mengkonversi data asli agar diperoleh data sesuai kebutuhan. Hasil segmentasi lebih baik setelah menambahkan preprocessing high pass low pass filtering untuk mengurangi noise pada citra warna [11]. Teknik preprocessing lain pada gambar berwarna untuk segmentasi citra dilakukan implementasi perbaikan kontras gambar sehingga menghasilkan segmentasi gambar yang baik [12]. Dari beberapa penelitian tentang segmentasi gambar, preprocessing sangat berpengaruh pada hasil segmentasi.

\section{Contrast Stretching}

Kontras dari suatu citra dapat dipengaruhi oleh pencahayaan, bidang dinamika dari sensor citra, atau kesalahan setting pembuka lensa pada saat akusisi citra. Contrast stretching dapat diterapkan untuk mendapatkan citra baru dengan kontras yang lebih baik dari citra asalnya. Perbaikan kontras citra dengan contrast stretching merupakan operasi titik pada citra asli, yang artinya proses ini hanya tergantung nilai intensitas (gray level) satu pixel dan tidak tergantung pada piksel lain disekitarnya. Proses dari contrast stretching dilakukan dengan meningkatkan bidang dinamika gray level pada citra yang akan diproses [13].

Contrast streching berguna untuk meningkatkan kekontrasan gambar yang kurang baik diakibatkan oleh pencahayaan yang buruk atau sensor kamera yang kurang luas daya tangkapnya. Perenggangan pada perenggangan kontras, setiap piksel pada citra $U$ ditransformasi dengan menggunakan fungsi 1:

$$
o(i, j)=\frac{u(i, j)-c}{d-c}(L-1)
$$

Dengan $o(i, j)$ dan $u(i, j)$ berturut-turut piksel sesudah dan sebelum ditransformasi pada koordinat $(i, j), c$ dan $d$ berturutturut menyatakan nilai maksimum dan minimum dari piksel pada citra input, dan $L$ menyatakan nilai grayscale maksimum. Bila nilai piksel lebih kecil dari 0 maka akan dijadikan 0 dan bila lebih besar dari $(L-1)$ maka akan dijadikan $(L-1)$ [13].

\section{Metodelogi Penelitian}

Pada paper ini dirancang implementasi contrast strecthing sebagai preprocessing pada proses segmentasi video pemantauan aktifitas garis pantai. Frame yang digunakan merupakan frame dari video hasil pemantauan aktifitas garis pantai. Akuisisi citra pemantauan aktifitas garis pantai dilakukan oleh Deltares Argus Archive [14]. Data frame video yang telah diunduh dari situs Deltares Argus Archive sebagai inputan pada sistem yang telah dibangun. Pembahasan dalam paper ini adalah kualitas cluster yang dihasilkan dari segmentasi dengan preprocessing contrast stretching. Hasil cluster dengan contrast stretching dibandingkan dengan segmentasi tanpa preprocessing. Perbandingan hasil cluster dibandingkan berdasarkan nilai validitas cluster. Metode yang digunakan untuk mengukur validitas cluster adalah silhouette coefficient.

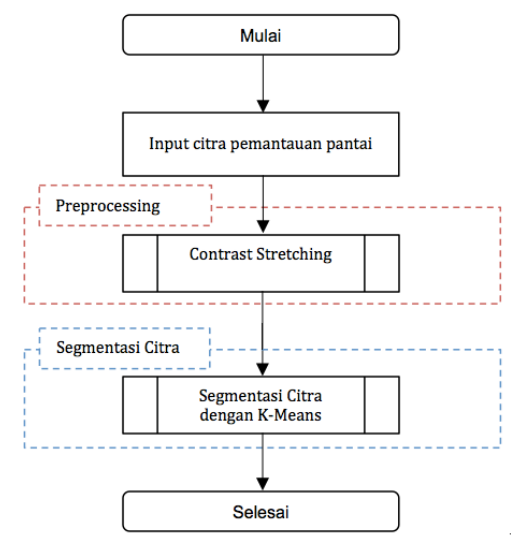

Gambar 1: Diagram Alir Perbaikan Kualitas Citra dengan Contrast Stretching pada Proses Segmentasi Citra

\section{A. Contrast Stretching}

Contrast stretching dilakukan untuk mendapatkan nilai RGB baru dengan kontras yang lebih baik. Dengan kontras yang baik pada citra, dapat meningkatkan ketajaman warna obyek pada citra. Obyek yang terlihat jelas pada citra dapat membantu pada proses segmentasi citra. Proses contrast stretching dilakukan dengan peregangan nilai RGB berdasarkan nilai maksimum dan minimum dari nilai RGB [15]. Penentuan nilai maksimum dan minimum pada paper ini ditentukan dengan fungsi stretchlim pada matlab.

range $=$ stretchlim $(\mathrm{RGB})$;

Nilai rentang minimum dan maksimum yang dihasilkan ditentukan sebagai parameter input pada proses peregangan kontras dengan fungsi imadjust pada matlab.

\section{newRGB = imadjust (RGB, range) ;}

Hasil dari proses contrast stretching dengan imadjust merupakan citra dengan nilai kontras yang baru. Setelah proses perbaikan kontras, citra kemudian diolah pada proses segmentasi dengan $k$-means.

\section{B. K-Means}

Algotritma K-Means digunakan pada proses segmentasi berdasarkan ciri RGB pada citra masukan yang telah melewati preprocessing. Hasil dari segmentasi ditentukan berdasarkan kemiripan atau kedekatan nilai ciri dengan pusat cluster. $K$ means mengelompokkan objek menjadi K cluster. Metode ini akan mencari pusat cluster dan batas-batas cluster melalui proses perulangan (iterative). Kedekatan atau kemiripan (similarity) suatu objek dengan objek lain atau dengan pusat kluster dihitung dengan menggunakan fungsi jarak pada umumnya K-means menggunakan jarak Euclidean untuk 
menghitung kemiripan tersebut [16]. Pada paper ini algoritma $k$-means digunakan dalam segmentasi citra berdasarkan warna dari frame input. Segmentasi dilakukan berdasarkan kemiripan (similarity) atau kedekatan pusat cluster dengan menggunakan jarak euclidean. Atribut dari piksel yang akan digunakan dalam proses segmentasi adalah indeks warna merah (R), indeks warna hijau (G), indeks warna biru (B).

\section{Silhouette Coefficient}

Silhouette coefficient mengkombinasikan ide cohesion dan separation untuk validasi hasil clustering. Cohesion digunakan untuk mengukur seberapa dekat hubungan objekobjek pada cluster yang sama. Sedangkan separation digunakan untuk mengukur seberapa berbeda atau terpisahnya sebuah cluster dari cluster lainnya. Sedangkan silhouette coefficient sendiri digunakan untuk mengukur kualitas cluster yang dihasilkan sekaligus mengindikasikan derajat kepemilikan setiap objek yang berada di dalam cluster. Nilai silhouette dari sebuah objek $O j$ berada pada rentang antara -1 sampai dengan 1. Semakin dekat nilai silhouette objek $O j$ ke 1, maka semakin tinggi derajat $O j$ di dalam cluster [17].

Diberikan sebuah titik $S_{i}$ di cluster $C_{l}$, lalu $a(i)$ adalah jarak rata-rata antara titik $S_{i}$ dengan titik lain di cluster $C_{l}$, dan $b(i)$ adalah jarak rata-rata antara titik $S_{i}$ dan titik-titik di cluster kedua yang terdekat dengan $C_{1}$, yaitu cluster $C_{2}$ dan $C_{3}$. Kemudian hitung nilai silhouette setiap objek dengan persamaan (2) :

$$
s(i)=\frac{b(i)-a(i)}{\max \{a(i), b(i)\}}
$$

Setelah mendapatkan nilai silhouette tiap objek dalam cluster, kita dapat menentukan silhouette width untuk cluster tersebut, yaitu dengan menghitung rata-rata nilai silhouette semua objek yang berada dalam cluster. Nilai silhouette width dinyatakan dalam rentang -1 sampai dengan 1, nilai silhouette width yang mendekati angka 1 memiliki derajat kepemilikan anggota pada cluster yang tinggi (kualitas cluster baik). Sebaliknya nilai yang mendekati angka -1 memiliki derajat kepemilikan anggota cluster yang salah (kualitas cluster tidak baik) [17].

\section{HASIL DAN PEMBAHASAN}

Contrast Stretching pada paper ini telah diuji pada kumpulan frame berwarna dari video hasil pemantauan aktifitas garis pantai. Simulasi dibangun dengan perangkat lunak Matlab 2014a, dan frame asli dapat dilihat pada Gambar 2. Gambar 2 (a), Gambar 2 (b), Gambar 2 (c), Gambar 2 (d), Gambar 2 (e), Gambar 2 (f), dan Gambar 2 (g) merupakan data uji frame video dengan komposisi cahaya matahari yang berbeda-beda.
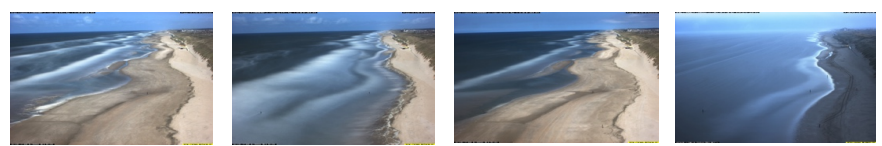

I Made Dwi Putra Asana: Metode Contrast Stretching untuk ... (a)

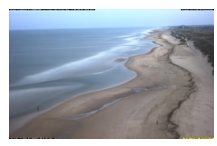

(e) (b)

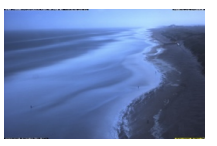

(f) (c)

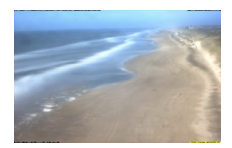

(g) (d)

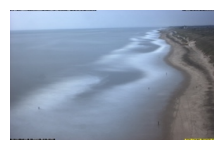

(h)
Gambar 2: Frame Asli : (a) Data 1, (b) Data 2, (c) Data 3, (d) Data 4, (e) Data 5, (f) Data 6, (g) Data 7, (h) Data 8

Pada Gambar 3 (b), Gambar 4 (b), Gambar 5 (b), Gambar 6 (b), Gambar 7 (b), Gambar 8 (b), Gambar (9), dan Gambar 10 (b) ditunjukan hasil perbaikan kontras citra dengan contrast stretching. Secara visual citra baru yang dihasilkan memiliki kontras yang lebih baik. Perbedaan warna dari obyek pada citra baru terlihat lebih jelas dari citra asli. Untuk mengetahui lebih jelas mengenai hasil operasi perbaikan kontras dari contrast stretching, dapat dilihat pada Gambar 9 yang merupakan histogram dari Data 1. Gambar 11 (a) menunjukan histogram dari frame asli dan Gambar 11 (b) histogram dari frame baru hasil contrast stretching. Dari histogram yang ditampilkan pada frame hasil contrast stretching, terjadi pelebaran nilai RGB yang menyebabkan penyebaran warna pada citra lebih merata. Gambar 12 merupakan histogram dari frame Data 2, Gambar 12 (a) adalah histogram dari frame sebelum diolah, dan Gambar 12 (b) merupakan frame baru hasi pengolahan contrast stretching.

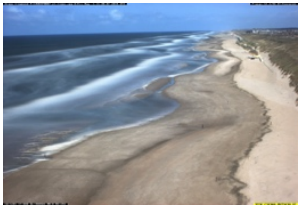

(a)

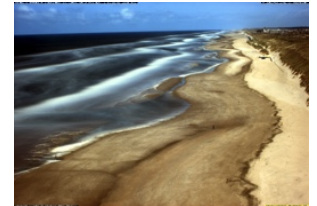

(b)
Gambar 3: Perbaikan Kontras dari Data 1 : (a) Citra Asli, (b) Hasil Contrast Stretching

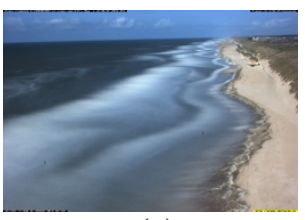

(a)

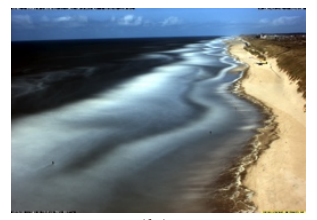

(b)
Gambar 4: Perbaikan Kontras dari Data 2 : (a) Citra Asli, (b) Hasil Contrast Stretching

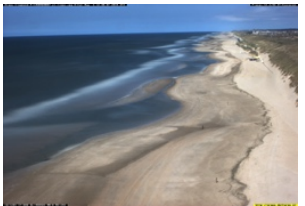

(a)

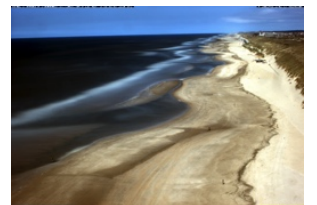

(b)
Gambar 5: Perbaikan Kontras dari Data 3 : (a) Citra Asli, (b) Hasil Contrast Stretching

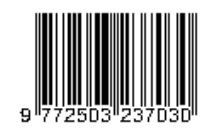




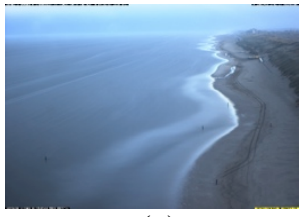

(a)

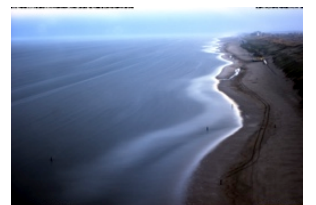

(b)
Gambar 6: Perbaikan Kontras dari Data 4 : (a) Citra Asli, (b) Hasil Contrast Stretching

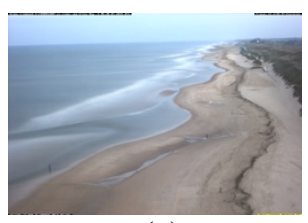

(a)

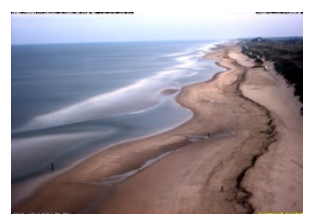

(b)
Gambar 7: Perbaikan Kontras dari Data 5 : (a) Citra Asli, (b) Hasil Contrast Stretching

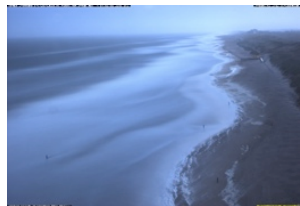

(a)

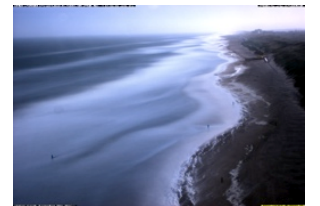

(b)
Gambar 8: Perbaikan Kontras dari Data 6 : (a) Citra Asli, (b) Hasil Contrast Stretching

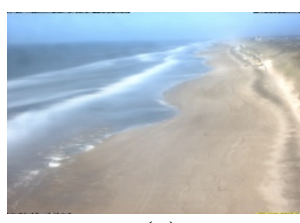

(a)

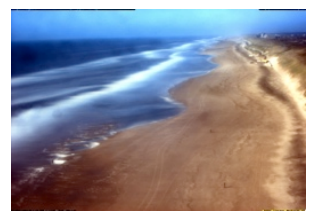

(b)
Gambar 9: Perbaikan Kontras dari Data 7 : (a) Citra Asli, (b) Hasil Contrast Stretching

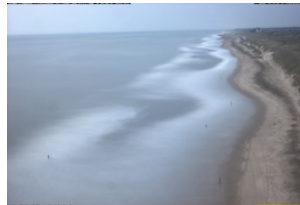

(a)

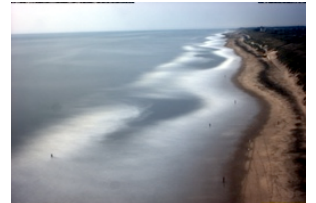

(b)
Gambar 10: Perbaikan Kontras dari Data 8 : (a) Citra Asli, (b) Hasil Contrast Stretching

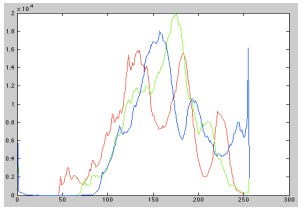

(a)

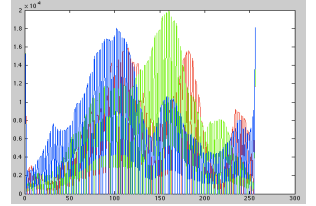

(b)
Gambar 11: Histogram dari Data 1 : (a) Frame Asli, (b) Hasil Contrast Stretching

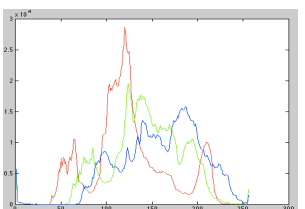

(a)

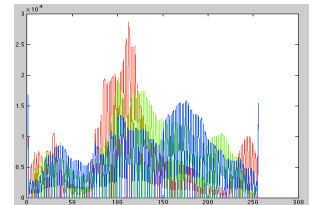

(b)
Gambar 12: Histogram dari Data 2: (a) Frame Asli, (b) Hasil Contrast Stretching

Setelah proses preprocessing dengan contrast stretching, selanjutnya dilakukan proses segmentasi citra dengan algoritma k-means. Pada proses segmentasi, jumlah cluster ditentukan sebanyak 3 cluster. Hasil segmentasi ditunjukan berdasarkan dengan preprocessing contrast stretching dan tanpa preprocessing. Hasil segmentasi kemudian diukur dengan metode silhouette coefficient untuk mengetahui kualitas cluster yang dihasilkan pada masing-masing pengujian segmentasi.

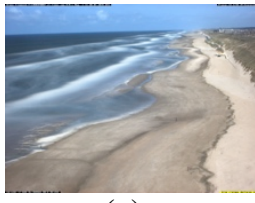

(a)

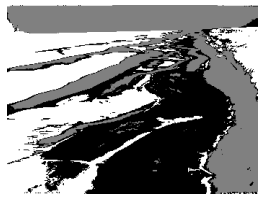

(b)

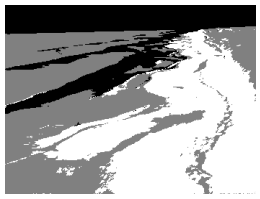

(c)
Gambar 11: Hasil Segmentasi Data 1: (a) Frame Asli, (b) Segmentasi Tanpa Preprocessing, (c) Segmentasi Citra dengan Preprocessing Contrast Stretching

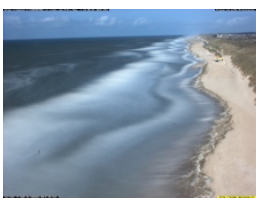

(a)

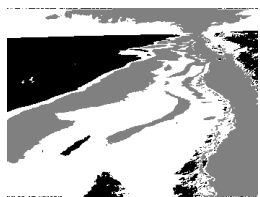

(b)

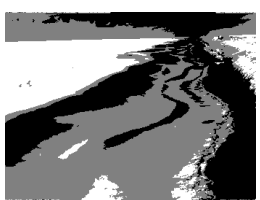

(c)
Gambar 12: Hasil Segmentasi Data 2 : (a) Frame Asli, (b) Segmentasi Tanpa Preprocessing, (c) Segmentasi Citra dengan Preprocessing Contrast Stretching

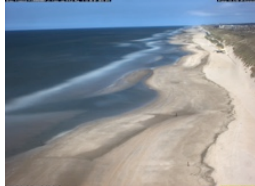

(a)

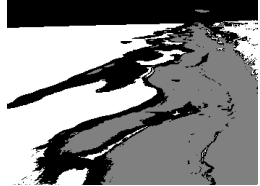

(b)

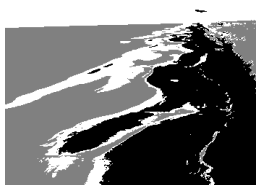

(c)
Gambar 13: Hasil Segmentasi Data 3 : (a) Frame Asli, (b) Segmentasi Tanpa Preprocessing, (c) Segmentasi Citra dengan Preprocessing Contrast Stretching

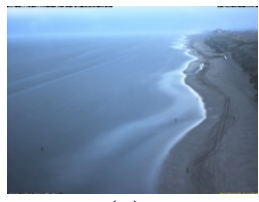

(a)

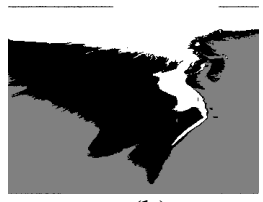

(b)

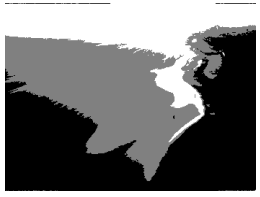

(c)
Gambar 14: Hasil Segmentasi Data 4 : (a) Frame Asli, (b) Segmentasi Tanpa Preprocessing, (c) Segmentasi Citra dengan Preprocessing Contrast Stretching 


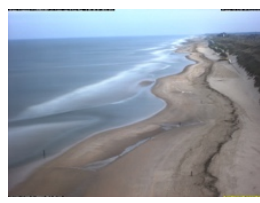

(a)

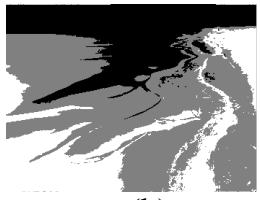

(b)

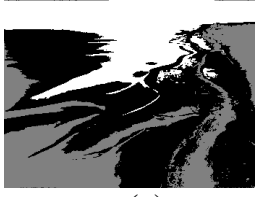

(c)
Gambar 15: Hasil Segmentasi Data 5 : (a) Frame Asli, (b) Segmentasi Tanpa Preprocessing, (c) Segmentasi Citra dengan Preprocessing Contrast Stretching

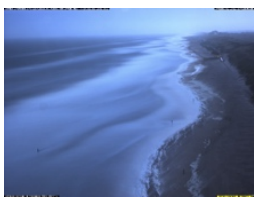

(a)

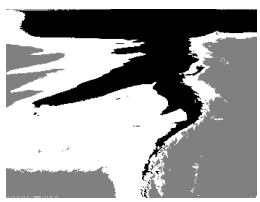

(b)

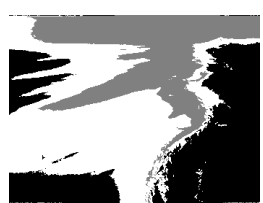

(c)
Gambar 16: Hasil Segmentasi Data 6 : (a) Frame Asli, (b) Segmentasi Tanpa Preprocessing, (c) Segmentasi Citra dengan Preprocessing Contrast Stretching

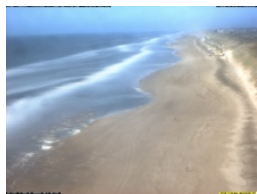

(a)

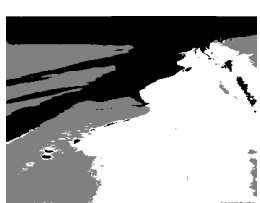

(b)

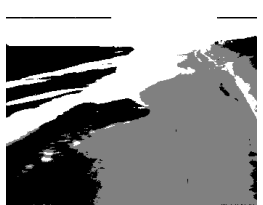

(c)
Gambar 17: Hasil Segmentasi Data 7 : (a) Frame Asli, (b) Segmentasi Tanpa Preprocessing, (c) Segmentasi Citra dengan Preprocessing Contrast Stretching

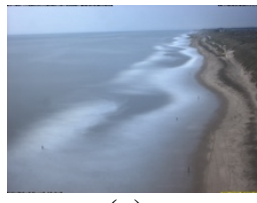

(a)

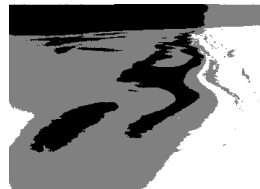

(b)

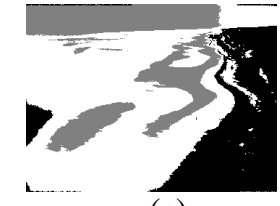

(c)
Gambar 20: Hasil Segmentasi Data 8 : (a) Frame Asli, (b) Segmentasi Tanpa Preprocessing, (c) Segmentasi Citra dengan Preprocessing Contrast Stretching

Gambar 13 sampai dengan Gambar 20 menunjukan hasil segmentasi tanpa preprocessing (b) dan dengan preprocessing contrast stretching (c). Pada hasil pengujian segmentasi cluster diberi label dengan warna putih, hitam, dan abu. Nilai silhouette width yang dihasilkan dari masing-masing hasil segmentasi ditunjukan pada Tabel 1.

TABEL I

HASIL NILAI SILHOUETTE WIDTH

\begin{tabular}{|c|c|c|c|}
\hline \multirow{2}{*}{ No } & \multirow{2}{*}{ Data } & \multicolumn{2}{|c|}{ Silhouette Width } \\
\cline { 3 - 4 } & Danpa & $\begin{array}{c}\text { Preprocessing } \\
\text { Preprocessing }\end{array}$ & \begin{tabular}{c} 
Contrast Stretching \\
\hline 1
\end{tabular} \\
\cline { 3 - 4 } & Data 1 & 0,5138 & 0,6403 \\
\hline 3 & Data 2 & 0,6278 & 0,6325 \\
\hline 4 & Data 3 & 0,6576 & 0,6564 \\
\hline 5 & Data 4 & 0,7553 & 0,7582 \\
\hline 6 & Data 5 & 0,6487 & 0,6451 \\
\hline 7 & Data 6 & 0,7074 & 0,7375 \\
\hline 8 & Data 7 & 0,6374 & 0,6427 \\
\hline
\end{tabular}

I Made Dwi Putra Asana: Metode Contrast Stretching untuk ...
Tabel 1 menunjukan hasil pengukuran kualitas cluster yang dihasilkan pada proses segmentasi tanpa preprocessing dan dengan preprocessing contrast stretching. Nilai silhouette width dinyatakan dalam rentang -1 sampai dengan 1 , nilai silhouette width yang mendekati angka 1 memiliki kualitas cluster yang baik. Sebaliknya nilai yang mendekati angka -1 memiliki kualitas cluster yang tidak baik. Berdasarkan nilai silhouette width pada Tabel 1, segmentasi tanpa preprocessing memiliki nilai silhouette width lebih tinggi dibandingkan dengan preprocessing pada Data 3 dan Data 5. Pada data no. 3 (Tabel 1) nilai silhouette width tanpa preprocessing lebih tinggi dengan 0,6576 dibandingkan dengan preprocessing yang bernilai 0,6564. Data 5 (Tabel 1) memiliki nilai silhouette width 0,6487 untuk tanpa preprocessing dan 0,6451 dengan preprocessing. Hal ini menggambarkan jarak antara cluster saat tanpa preprocessing lebih jauh dibandingkan dengan preprocessing contrast stretching. Penyebab dari nilai silhouette width lebih besar tanpa preprocessing adalah nilai antar obyek dalam satu cluster cukup dekat dan nilai obyek dengan obyek pada cluster lain lebih jauh. Ketika dilakukan preprocessing nilai obyek pada citra berubah, dan perubahan nilai tersebut mempengaruhi jarak antara obyek di dalam cluster dan dengan obyek pada cluster berbeda. Pada percobaan dengan Data 3 dan Data 5, perubahan nilai obyek saat dilakukan preprocessing menurunkan nilai silhouette width. Hal tersebut terjadi karena karakteristik data yang diuji. Dari delapan data yang diuji pada Tabel 1, enam data yaitu Data 1, 2, 4, 6, 7, dan 8 menunjukan segmentasi dengan preprocessing contrast stretching memiliki nilai silhouette width lebih tinggi. Hal tersebut dapat dilihat pada Data 1 dengan nilai 0,5138 untuk tanpa preprocessing dan 0,6403 dengan preprocessing. Data lain yang menunjukan segmentasi dengan preprocessing lebih tinggi yaitu pada Data 2 yang memiliki nilai 0,6325 dan 0,6278 untuk tanpa preprocessing.

\section{KESIMPULAN}

Pada paper ini telah dibahas penerapan metode contrast stretching sebagai preprocessing dalam hal perbaikan kualitas citra pada proses segmentasi video pemantauan aktifitas garis pantai. Dari hasil pengujian contrast stretching dapat diterapkan pada citra berwarna berbasis video menggunakan Matlab. Perubahan yang terjadi setelah dilakukan pengolahan frame dengan contrast stretching dapat dilihat secara visual dan dalam bentuk histogram. Perbaikan kualitas citra dengan contrast stretching dapat meningkatkan kualitas hasil segmentasi frame video menggunakan algoritma $k$-means. Hal tersebut dapat dilihat dari delapan percobaan enam diantaranya yaitu data $1,2,4,6,7$, dan 8 memiliki nilai silhoute lebih tinggi ketika dilakukan preprocessing sebelum proses segmentasi. Nilai silhouette width menunjukan kualitas cluster berdasarkan derajat kepemilikan setiap obyek di dalam cluster. Nilai silhouette memiliki rentang -1 sampai dengan 1, nilai yang mendekati angka 1 memiliki kualitas cluster lebih baik.

p-ISSN:1693 - 2951; e-ISSN: 2503-2372

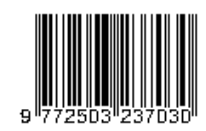




\section{REFERENSI}

[1] Ismail, Hariadi,Mochamad, Purnama,I Ketut Eddy, "Sekmentasi Video dengan Metode Algoritma Ekspektasi Maksimum pada Event Outdoor," Seminar Nasional Electrical, Informatics, and It's Education 2009.

[2] Santony,Julius, "Konversi Video AVI ke Video MPEG Dengan Menggunakan Matlab," Jurnal Teknologi Informasi \& Pendidikan, Vol. 6, No. 2, 2013

[3] Widyantara, I M.O., Wirawan, and Hendrantoro, G., 2012, "Reducing Decoding Complexity by Improving Motion Filed Using Bicubic and Lanczos Interpolation Techniques in Wyner-Ziv Video Coding", KSII Transactions on Internet and Information System, 9(6), pp. 2351-2369.

[4] Widyantara, I Made Oka., "Decoding Approach With Unsupervised Learning of Two Motion Fields For Improving Wyner-Ziv Coding of Video", International Journal of Applied Engineering Research, Vol. 10, No. 5 pp. $11763-11776,2015$

[5] Widyantara, I Made Oka, Kusuma, Agus Tommy Adi Prawira, Wirastuti, Ni Made Ary Esta Dewi, "Preprocessing Pada Segmentasi Citra Paru-Paru Dan Jantung Menggunakan Anisotropic Diffusion Filter," Teknologi Elektro, Vol. 14,No.2, Juli-Desember 2015.

[6] Adnyana, I Made Budi, Putra, I Ketut Gede Darma, Bayupati, I Putu Agung, "Segmentasi Citra Berbasis Clustering Menggunakan Algoritma Fuzzy C-Means,” Jurnal Teknologi Elektro, Vol.14, No.1, Januari-Juni 2015.

[7] Nugraheni,Murien, "Aplikasi Transformasi Watershed Untuk Segmentasi Citra Dengan Spatial Filter Sebagai Pemroses Awal," Seminar Nasional Informatika 2010 (semnasIF 2010).

[8] Chen,Tse-Wei, Hsu,Shou-Chieh, Chien,Shao-Yi, "Robust Video Object Segmentation Based On K-Means Background Clustering And Watershed In Ill-Conditioned Surveillance System,” ICME 2007
[9] Widyantara,I Made Oka, Wirastuti,N.M.A.E.D, Asana,I Made Dwi Putra, Adnyana,Ida Bagus Putu, "Image Enhancement Using Morphological Contrast Enhancement for Video Based Image Analysis," Submitted at $3^{\text {rd }}$ International Conference on Data and Software Engineering, 2016.

[10] Jain,A.K, Fundamentals of Digital Image Processing, Prentice Hall of India, 1989

[11] Murinto, Harhoko,Agus, "Segmentasi Citra Menggunakan Watershed dan Intensitas Filtering Sebagai Pre Processing," Seminar Nasional Informatika 2009.

[12] Salihah, A. N. Aimi, M. Y. Mashor, N. H. Harun, A. A. Abdullah and H. Rosline, "Improving colour image segmentation on acute myelogenous leukaemia images using contrast enhancement techniques," Biomedical Engineering and Sciences (IECBES), 2010 IEEE EMBS Conference on, Kuala Lumpur, 2010, pp. 246-251.

[13] Wakhidah, Nur. "Perbaikan Kualitas Citra Menggunakan Metode Contrast Stretching (Improvement of image quality using a method Contrast Stretching), ” Jurnal Transformatika, Vol.8, No.2, 2011.

[14] Deltares Argus Archive. (2016) Site NL : Egmond (Coast3D tower), Noord Holland. [Online]. Available: http://arguspublic.deltares.nl/archive/

[15] Gusa,Rika, Favoria, "Pengolahan Citra Digital untuk Menghitung Luas Daerah Bekas Penambangan Timah,” Jurnal Nasional Teknik Elektro,Vol. 2, No.2, September 2013.

[16] Putra, Darma, Pengolahan Citra Digital. Yogyakarta : Penerbit Andi, 2010.

[17] Rousseeuw, P. J., "Silhouettes: a graphical aid to the interpretation and validation of cluster analysis," Journal of Computational and Applied Mathematics, vol. 20, 1987. 